\title{
Kitab-1 Bahriye (Book of Navigation), Commemoration of the Pîrî Reis and Understand His World Map of 1513.
}

\author{
Aytaç YÜRÜKÇÜ ${ }^{\mathrm{a},}$ * \\ ${ }^{a}$ Ass. Specialist \& PhD. Student, Turkish Historical Society, Ankara, TURKEY, aytacyurukcu@hotmail.com
}

\begin{abstract}
Many literary or scientific works had reached immortality by either its content or the author. Without a shadow of a doubt, Pîrî Reis' major work, a navigation book titled Kitab-1 Bahriye is one of those works that are passed down from generation to generation, light the way of historical process with the intense knowledge it contains, and guide researches and navigators. In Kitab-1 Bahriye which was written as a guide for navigators, sea towns are plotted in maps, bays are denoted, and information about ports for ships to berth, shoals, castles and habitants of these places are given. Furthermore, this work, as a reference book, has a very important place for geographical discoveries where experiences and fund of scientific knowledge accumulated for ages were verified and transmitted through generations in great detail. Kitab-1 Bahriye and world map of Pîrî Reis dated 1513 is not only a source for discoveries, navigation, cartography and cartography works but also it contains important and valuable data about word history and experiences, myths, values and historical positions of societies in 16th century. So much so that information in the book is ranging from Aegean and Red Sea to China Sea, from Indian Ocean to Japanese Sea.
\end{abstract}

In this article, it will be focused on how Pîrî Reis plotted such a precious map in that ages, from which books and works he got inspired while working on it, in which coasts he made observations and how he used these observations on his world map of 1513 and his unique work called Kitab-1 Bahriye. Being able to be studied by researchers after centuries, these two precious works also draw attention to how this kind of documents can be protected carefully for long duration in archives and museums. Lastly, with the examination of maps and drawings that have a past of 506 years, it is aimed at to understand mind world and all works of famous scientist Pîrî Reis who was commemorated by UNESCO in 2013 better and to share his impressions about new world geography in detail with researchers.

Keywords: Kitab-1 Bahriye (Book of Navigation), The World Map of 1513, Pîrî Reis, History of Cartography.

\section{Introduction}

- This article will be approached in three different tittles as following:

- To examine Pîrî Reis and his life,

- To examine Kitab-1 Bahriye, (Book of Navigation)

- To examine Pîrî Reis maps (1513 and 1528)

for making the subject more understandable. Undoubtedly, many studies on Pîrî Reis and Ottoman cartography had itself a place on differents sources, were researched and put at the disposal of researchers but there are quite a little studies on this field within International Cartographic Association and International Cartographic Journal. In this study by focusing mainly on Pîrî Reis, who has an important place in Ottoman cartography history and maybe even in world literature of cartography, and his maps dated 1513 and 1528, it is aimed at to give information about his features that haven't been examined within International Cartographic Association before. The map dated 1513 mentioned in this study is plotted by Pîrî Reis by benefiting from
Cristof Colomb's world map and from this aspect it has great importance for world cartography and geographical discoveries.

\section{Pîrî Reis and His Life in $16^{\text {th }}$ Century}

A Turkish Admiral Pîrî Reis, with his two world maps and his book Kitâb-i Bahriyye, became one of the most important representatives of marine geography not only in Ottoman Empire but also in the world. Great navigator Pîrî Reis is agreed to be born in Gallipoli ${ }^{1}$, an Ottoman nautical town (). Even his exact birth date is unknown, it was shown as between the years 1465-1470 (İnan, 1983, 9). The word "Pir" had been using in the meaning of "tutor of a profession, starter and teacher of a craft" along with the meaning of old and aged (Develioğlu, 1993). When his writings in his Kitab-1 Bahriye and events in history are compared, it is understood that he might have been born after 1465. His father was Hacı Mehmed and his uncle, one of the famous admirals of the period, Kemal Reis.

\footnotetext{
${ }^{1}$ Gallipoli is an important naval base along the Marmara coast.
} 
When Pîrî was about eleven, he joined the crew of his uncle who had started out as a pirate and then joined the Imperial Ottoman fleet. Between 1487 and 1493, Pîrî participated in many naval battles with his uncle. His independent career as naval captain corresponds to his heroic performances in the sea battles between 1499 and 1502. It is probably during one of these battles that he may have gotten hold of the Columbus Map. After his uncle's death in 1511, he left the open seas to live in Gallipoli and started working on map drawing. After a while, he joined in the crew of the great Turkish sailor Barbaros Hayrettin (Barbarossa Hayr al-Din). According to Kâtib Çelebi, after the death of Kemal Reis, Piri Reis worked with Barbaros, as well. (Katip Çelebi, 1980, 4243). After that, Piri Reis stayed in Gallipoli for a while and prepared his world map. The copy of the map we have today which shows east coasts of Central and South America and west coasts of Europe and Africa is a part of this world map. (Topkap1 Palace Museum Library, Revan, 1633).

Piri Reis' map discovered by Halil E. Eldem ${ }^{2}$ in 1929. Halil examined this map together with Professor Kahle, the German orientalist, then a visitor in İstanbul and result of these investigations was made known by Professor Kahle at the XVIIIth Congress of Orientalists, which met in September 1931 in Leiden, Holland. Then Kahle published an article titled "The lost Columbus map of 1498: Discovered in a Turkish map of the world of 1513" and introduced the map to the science world. He did not only give broad information about the map but he also shared two photos of it. Thus this important world map shared with the science world and created a tremendous impact. ${ }^{3}$

The creator of the map, Pîrî Reis did not only hold office as a fleet commander but he was also interested in navigation, cartography and cartographic sciences. He gathered all his knowledge and experience on navigation together in his work called Kitab-1 Bahriye.

Piri Reis found the opportunity to use his experiences he gained in early ages and his knowledge on Ottoman navigation when Ottoman Empire having hard time in Mediterranean and he was promoted to fleet commander.

Piri Reis, in his map of 1513 he presented to Yavuz Sultan Selim in Kahire, in 1517, he wrote about his life and his aim to draw this map as:

"And this poor (man), I made a map once and in this map I stated many times more places and information compared to the maps that have been using, I enregistered

\footnotetext{
${ }^{2}$ He was a director of National Museum, in 1929, when the Palace of Topkap 1 He was a director of National Museum, in 1929, when the Palace of Topkapı was being turned into a museum of antiquties. $\mathrm{He}$ is one of the prominent figures who developped modern museology in the Ottoman Empire and specialized in numismatics, archeology, epigraphy,genealogy and history.

${ }^{3}$ Kahle's these studies along with his other studies anout cartography were published in Spanis and Italian. Wide-reaching information on this map was given by Oberhummer, Professor of Geography in Vienna University, in Vien Academy in 1931.
}

Indian and Chinese seas, and information in new maps which are seen and known by no one in Ottoman country. That map was presented to the door of happiness of deceased Sultan Selim Han, may his soil be spotless and in heaven, and it was approved." ()

Piri Reis found the opportunity to observe Nile River closely during Egypt campaign and having drawn important maps of these places he put them into Kitab-1 Bahriye.

Pîrî Reis who transmitted his knowledge and experience in Ottoman Navy for a long time, gathered all his experience and drawings in his work called Kitab-1 Bahriye. Lastly he was appointed as Indian Captain in East Mediterranean of Ottoman Empire and he tried to order and regulate Suez fleet. After the discovery of Good Hope Cape, activities of Portuguese in this area speeded up. Their activities in the Persian Gulf in 1550 and 1551 turned political and economic developments against Ottoman Empire.

Even though Pîrî Reis who read these developments and technical supremacy of Portuguese ships well, made some technical and scientific points for renewing and developing Ottoman fleet in this area, in 1554, by order of Kanuni Sultan Süleyman first he was expropriated and then he was executed in Cairo being a victim of various plots. It is undoubtedly obvious that Muhyiddin Pîrî Reis, lived guessingly for about 85 years, had gave important service to Ottoman navigation and world history of cartography.

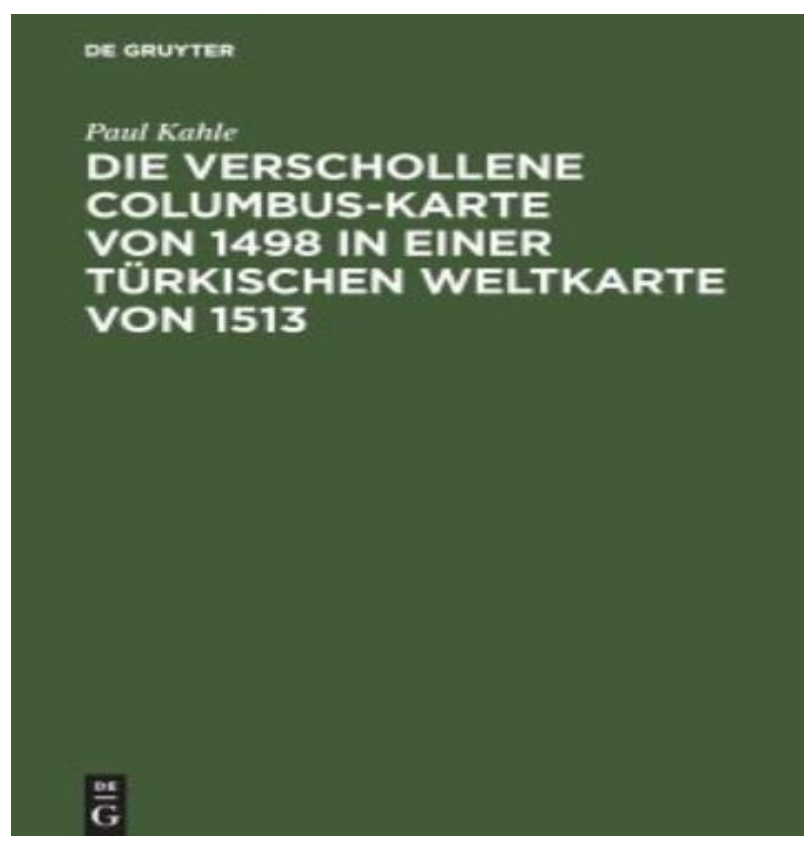

Figure 1: Die Verschollene Columbus-Karte von 1498 in einer Türkischen Weltkarte von 1513 (The Lost Map of Colombus, 1498. In A Turkish General Chart of 1513). by Paul Ernst KAHLE. (Walter de Gruyter \& Co., Berlin and Leipzig, 1933, 52 pp. 9 facsimile charts.) 


\section{Kitab-1 Bahriye (927-932 AH) 1521-1526 CE (The Book of Navigation)}

The book called Kitab-1 Bahriye (Book of Navigation on Mediterranean Coasts) gives a lot of key information about the Mediterranean Sea, cities and towns on the Mediterranean coast and islands with illustrations and text on navigation and seafaring. Piri Reis first wrote Kitab-1 Bahriye in $927 \mathrm{AH} / 1520-1521 \mathrm{CE}$ and then added other parts of book in $932 \mathrm{AH} / 1525-1526 \mathrm{CE}$.

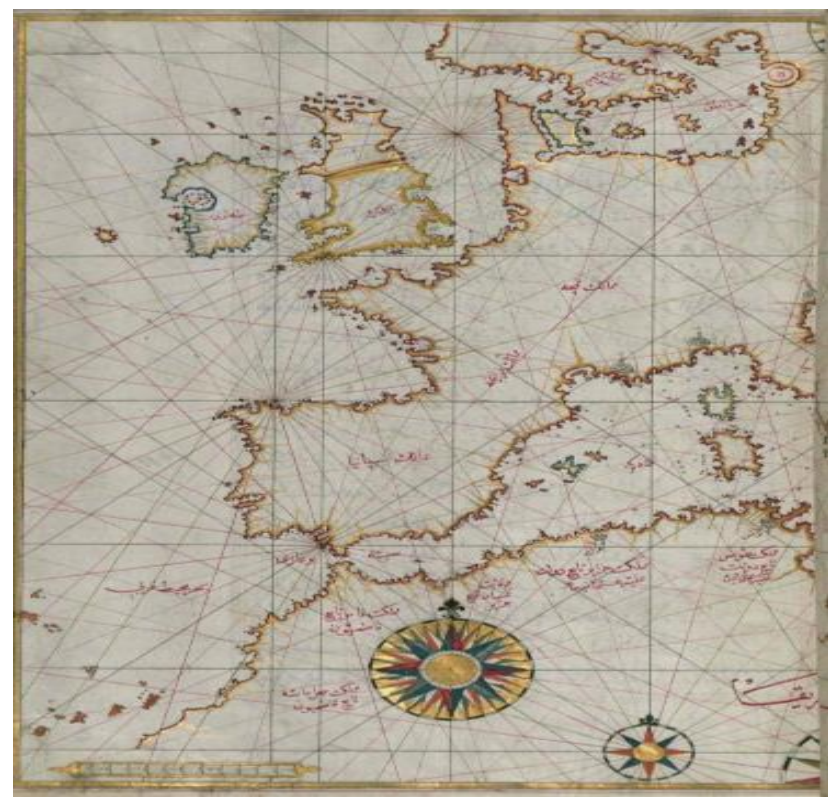

Figure 2: The Map of Europe from Piri Reis, "Kitab-1 Bahriye" second version, 1525-1526. Manuscript copied in 17th century, İstanbul University Library, İstanbul (T. 6605).

The compilation by Pîrî Reis of his monumental undertaking, the Kitâb-1 Bahriye, was completed in h.928 (1521) of 130 chapters, with a second longer presentation version made at the request of the Vizier to Sultan Süleyman, Ibrahim Pasha, of 210 chapters and containing anb extensive informative poem and was completed by $\mathrm{h}$. 932 (1526) and The Navigation Book of Bahriye was produced from a copy of the extended 1526 presentation version. When we read the Kitab-1 Bahriye, we can also understand that Piri Reis explains a lot about geography and gives advice to sailors to get a better understanding of the coast and cultures more. Moreover, Mediterranean islands and coastal settlements, ruins, harbors, waters, stones and shallows on which side of the harbor in

\footnotetext{
${ }^{4}$ Kitab-1 Bahriye has a limited number of original copies preserved in various museums across Europe. 29 copies of Kitab-1 Bahriye still exist, 16 of which date back to 1521 in İstanbul, Dresden, Bologna, Berlin, Paris, Vienna and London, and 13 of which date back to 1526 in İstanbul. Prof. Svat Soucek claims that there are 38 copies with two different versions and with text, without text and unknown (Soucek, 1992, 290-291 his appendix 14.2, Preliminary list of extant manuscripts of the Kitab-1 Bahriye, in this article we can find all types of copies in detailed.) and Özen claims that there are 42 copies (Özen, 1998, 20-21), for Sarıcaoğlu there are roughly 60 copies (Sarıcaoğlu, 2002, 73).
}

question, which wind is open or closed, the width of the harbor or narrow, how long the ship can harbor, shore and their distance to each other.

In a specific chapter of Kitab-1 Bahriye, Piri Reis says that he abided by the internationally approved map cartography traditions of his time. Cities and castles are shown by red stripes, desolate places by black stripes, debris and giblets by black points, shallows and sandy places by red points and secret rocks by crosses.

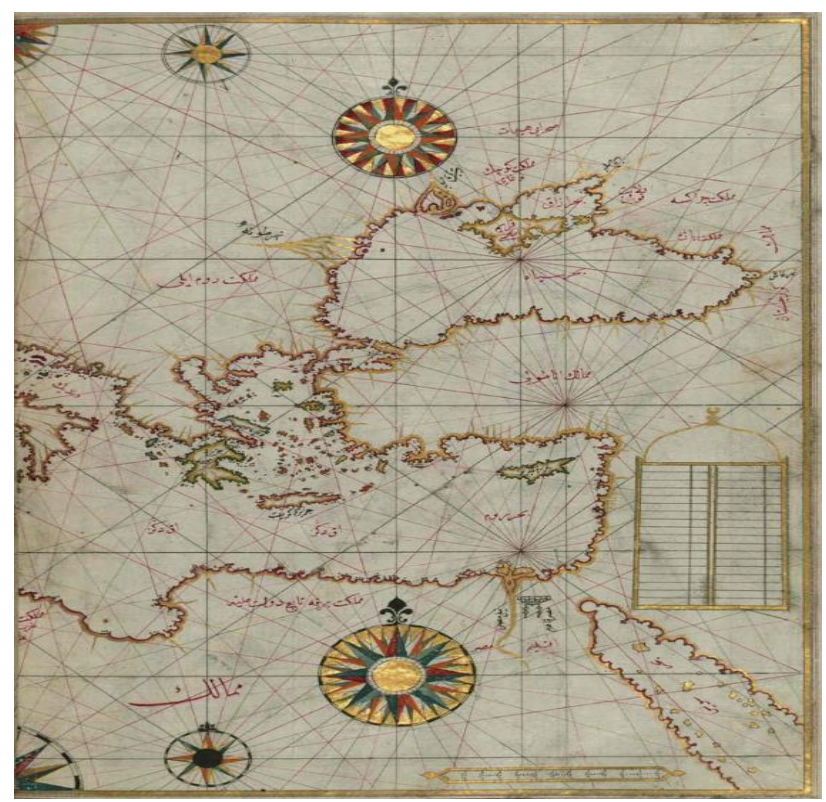

Figure 3: The Map of Europe from Piri Reis, "Kitab-1 Bahriye," second version, 1525-1526. Manuscript copied in 17th century, İstanbul University Library, İstanbul (T. 6605)

The fact that the discovery of the new world at the end of the 15th century and the beginning of the 16th century, though not directly related to the interests of the Ottoman Empire, was closely and attentively followed by the Turkish intellectuals and their remarkable talent in map drawing and geography demonstrate the presence of Turks within the European civilization at that time. This is confirmed by Kitab-1 Bahriye, since it is among the best of works on the Mediterranean of the time.

Kitab-1 Bahriye is in four parts: Introduction, Verse, Prose and Conclusion. The book contains a lot of detailed information about physical geography (tombolos, deltas, coastal shapes) and human geography (tents, villages, castles, cities, bridges, harbors and ships), underwater topography (shallow fields, harbors, cliffs), climate characteristics (wind, rain, temperature), stream sources (creeks, streams, springs and water wells), coastal shapes, animals (fish and fishing, sheep, goats, gazelles, wild boars, rabbits), soils, structure of mountains and agriculture and farming, vegetation cover (juniper, acorn, pine, witch elms, fig tree, olive groves, citrus gardens). Furthermore, economic activities (coal quarries, stone quarries, marble quarries), mines, administrative and political structures (borders and countries), map marks and various directional information and details are illustrated with specific different icons and symbols. It 
also offers information about history, maps, cartography, general geography, economic structures, social life, shipping knowledge and techniques from the 15 th century and his final experiences.

It is certain that Kitab-1 Bahriye was composed by making use of the earlier maps and developing with new studies. It is thought that some Catalan, Portuguese and Italian portolon maps that were used in navigations and research in the Mediterranean in the 15th century and Italian island books (isolario) of the 15th century were used as a contribution to Kitab-1 Bahriye. For the islands of the Aegean Sea, isolario of Bartolommeo (Venice 1484-1486), because of their resemblance in style, works that were started by C. Boundelmonti and developed by B. Bartolommeo dalli Sonetti and B. Bordone, are probably are the miniatures depicting Venice in the Kitab-i Bahriye. Here, Sicilian island, Italian peninsula, Adriatic sea and French coasts are particularly mentioned. (Soucek 1992, 276-80).

\section{Piri Reis' World Maps}

\subsection{The First World Map of Piri Reis 1513}

Piri Reis's Map of 1513 is one of the most detailed and beautiful, interesting and significant portolan in the historyof cartography and geographical resourses. Piri Reis spent most of his life at sea, especially in the Mediterranean. Carefully observing the places he visited and combining his observations with his experience and skills in cartography (McIntosh, 2000). The First World Map of Piri Reis 1513 was meticulously drawn on antelope skin in colour. The part of the map we have at hand is the piece of a world map. It is clear to an attentive eye that the notes in the eastern side are cut in half, we may thus deduce that the entire map shows then discovered parts of the world, namely Europe, Asia and Africa.

In a note attached to the map, Piri Reis explained the maps he had seen and investigated while he was composing his own map. The notes on the Antilles coasts tell that he benefited from the map of Christophe Columbus for these coasts and islands. He also tells cruise memories of a Spanish kept by his uncle Kemal Reis as a slave telling he visited America three times wity Christophe Columbus. He also says that he has seen the new maps of four Portuguese in his notes on the Southern America. the work is a wide world map, he had also investigated some maps showing the old world, maps composed in "the times of Alexander" as he put forward, "Mappamondos" and eight pieces of maps composed by the Muslims. Unfortunately, the valuable map we currently have at hand is only a part of the entire map. If the other parts had been lost, we would have had a perfect Turkish map composed 1513 showing both the old and the new map. Considering the fact that the journeys of Christophe Columbus date back to the end of $15^{\text {th }}$ century and the first years of the $16^{\text {th }}$ century (Columbus had turned from his fourth voyage in 1504), such a map composed just a while later than the new discoveries is one of the first maps showing the entire world.
Piri Reis wrote some explanations on the world map of 1513, and these notes are very important for sailros and cartographers, as well as historians. It is possible to read and explain what he wrote on the map clearly.

\subsection{Explanatory Remarks in the World Map of Piri Reis $1513^{5}$}

1. A red dye in this land is derived from a tree called Vakami, which can't be seen at first sight. Over the the mountains which are rich in mineral deposits, there are many sheep, wool of which is used for making silk threads one can easily untie. (Piri Reis Map, 2014, 7).

2. The people of these inhabitable countries wander and walk naked. (Piri Reis Map, 2014, 7).

3. In this region called Antilia and positioned in the west, there are four kinds of parrots: white, red, green and black. The people wear headpieces made of the feathers of the parrots, and eat their flesh. We saw avery hard type of stone here which looked like black touchstone and used by people to make ox. (Piri Reis Map, 2014, 7).

4. This map has drawn by Piri Inb Hacı Mehmet (Piri Reis), the nephew of Kemal Reis, in Gallipoli between March 9th and April $7^{\text {th }}$ of the year 1513.

5. This section explains how these shores and islands were discovered. (Piri Reis Map, 2014, 7).

It has been said that a Genoese called Christopher Columbus discovered these coasts are called the shores of Antilia. They were discovered in the year 896 of the Arab calendar. But it was rumoured thus, that a Genoese infidel called Colombo, was the one who discovered these places. For instance, a book came into the hands of the said Colombo, and he found it said in this book that at the end of the Western Sea (Atlantic), that is, on its western side, there were coasts and islands and all kinds of metals and also precious stones. The above-mentioned, having studied this book thoroughly, explained these matters one by one to the lords of Genoa and said: Come, give me two ships, let me go and find these places. They said: O, unprofitable man, can an end or limit be found to the Western Sea? Its vapour is full of darkness. The above-mentioned Colombo saw that no help was forthcoming from the Genoese, so he sped forth, went to the Bey of Spain (King) and told his tale in detail. They too answered like the Genoese. In short, Colombo petitioned these people for a long time, finally the Bey of Spain gave him two ships, saw that they were well equipped and said: $O$, Colombo, if it happens as you say, let us make you Kapudan (Admiral) to that country. The late Ghazi Kemal had a Spanish slave. The above-mentioned slave told Kemal Reis that he had been three times to that lands with Colombo. He said:

"First we reached the straits of Gibraltar, then from there straight south and west between the two. . .

\footnotetext{
${ }^{5}$ Because of the limited pages of article we can't share all detailed notes about map, but it will be declared in presentation clearly.
} 
Having advanced straight four thousand miles, we saw an island facing us, but gradually the waves of the sea became foamless, that is, the sea was becalmed and the North Star- the seamen still call it star on their compasses-little by little veiled and became invisible; and he also said that the stars in that region are not arranged as here. They are seen in a different arrangement. They anchored at the island which they had seen earlier across the way. The population of the island came, shot arrows at them and did not allow them to land and ask for information. The males and females shot hand arrows. The tips of these arrows were made of fish bones, and the whole population went naked. Seeing that they could not land on that island they crossed to the other side of the island and they saw a boat. On seeing them, the boat fled and they (the people in the boat) dashed out on land. They (the Spaniards) took the boat. They saw that inside of it there was human flesh. It happened that these people were of that nation which went from island to island hunting men and eating them. They said Colombo saw yet another island, they neared it, and they saw that on that island there were great snakes. They avoided landing on this island and remained there seventeen days. People of this island saw that no harm came to them from this boat. They caught fish and brought it to them in their small boat (filika)...

These (Spaniards) were pleased and gave them glass beads. It appears that he (Colombo) had read in the book that in that region, glass beads were valued. Seeing the beads, they brought still, more fish. These (Spaniards) always gave them glass beads. One day they saw gold around the arms of a woman; they took the gold and gave her beads. They told them: 'bring more gold, and we will give you more beads. They went and brought them much gold. It appears that in their mountains, there were gold mines. One day, also, they saw pearls in the hands of one person. They saw that when they gave beads, many more pearls were brought to them. Pearls were found on the shores of this island, in a spot one or two fathoms deep. And also leading their ship with many logwood trees and taking two natives along, they carried them within that year to the Bey of Spain. But the said Colombo, not knowing the language of these people, they traded by signs, and after this trip, the Bey of Spain, sent priests and barley, taught the natives how to sow and reap and converted them to his own religion. They had no religion of any sort. They walked naked, lay there like animals. Now, these regions have been opened to all and have become famous. The names, which mark the places on the said islands and coast, were given by Colombo so that they may know these places. And also Colombo was a great astronomer. The coasts and the islands on this map are taken from Columbus's map."(İnan, 1983, 30-31, (Piri Reis Map, 2014, 7-8, (Tekeli 1985, 276-7).

\subsection{The Second Map of Piri Reis 1528-1529}

The map starts with Greenland in the north. Towards the south there are two pieces of land, the first is called
Baccalo, the second one further down is called Terra Nova and it is mentioned that the Portuguese discovered these. Further south there is the peninsula of Florida drawn quite correctly and which Pîrî Reis names San Juan Batisto. This name was given to Puerto Rico on the previous map. The pieces of land at the side are the peninsulas of Honduras and Yucatan, discovered in 1517 and 1519 respectively (Tekeli 1985, 279).

\section{Appendix}

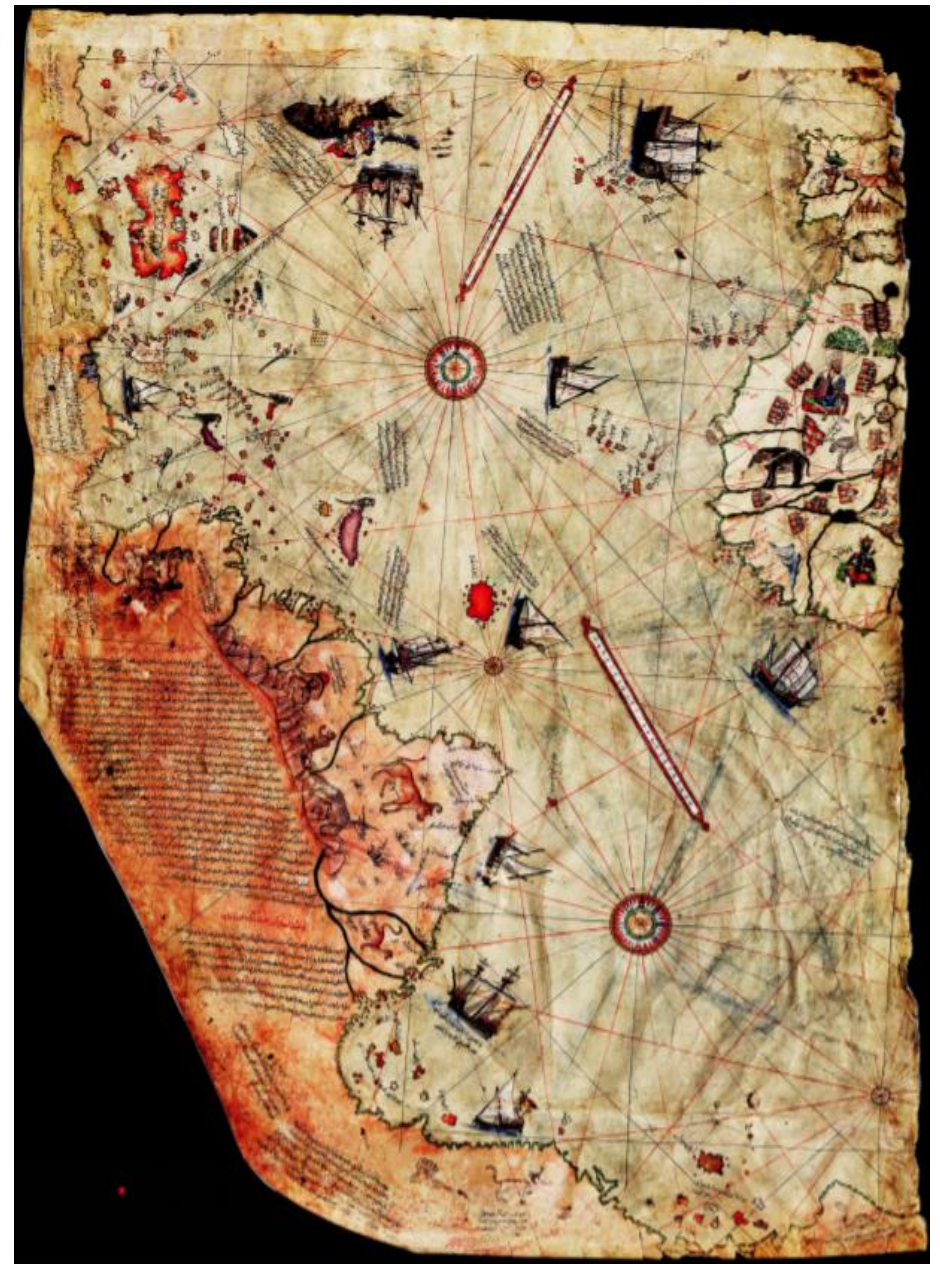

Appendix 1: The First World Map of Piri Reis 1513. The First World Map of Piri Reis was producted in 1513, it shows the Atlantic with the coasts of Europe, New World and Africa Continental. The World Map of 1513 discovered in 1929 at the Museum of Topkapi Palace. (The Author will share this uniq map with participants, in Engilish, French, Italian, Portuguese and Russian Languages version.) Topkapı Sarayı Museum Library, İstanbul (Revan 1633). 


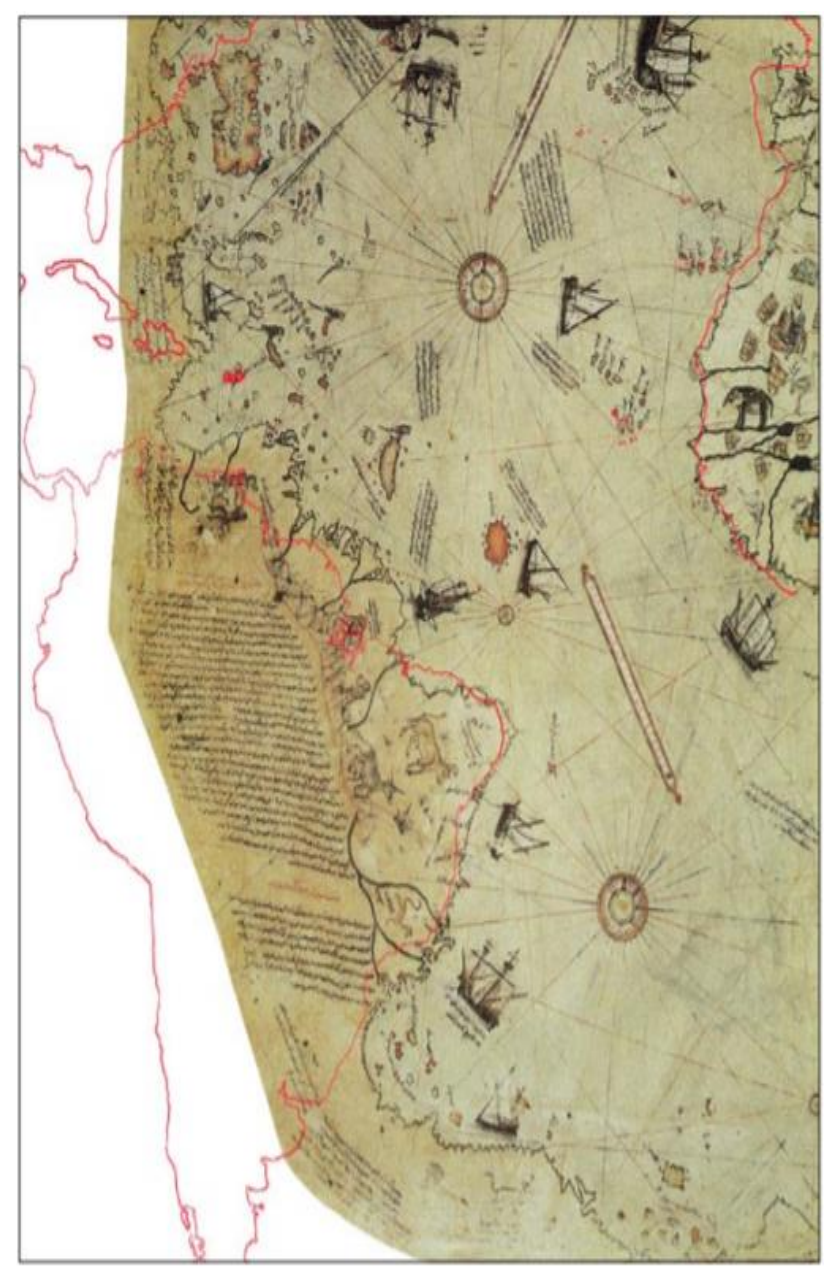

Appendix 2: Projection of the Pīrī Re, is-map on the modern atlas.

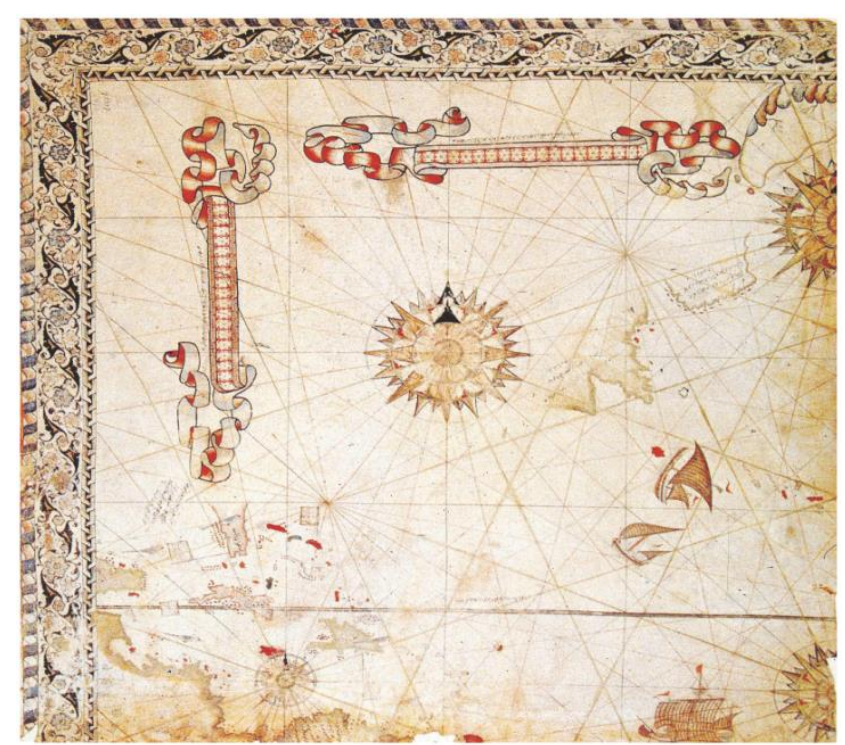

Appendix 3: The Second Map of Piri Reis 1528-1529. The World map of Piri Reis was made from 1528-29 and it covers the North western part of the Atlantic Ocean, The Caribbean Sea, Venezuella and as well as the Greenland. Topkapı Sarayı Museum Library, İstanbul (H. 1824, Revan 1633).

\section{References}

Develioğlu, Ferit, (1993). Osmanlıca Türkçe Lugat, 11. Bask1, 1993, Ankara.

İnan, Afet, (1983). Piri Reis'in Hayatı ve Eserleri (Piri Reis, His Life and Works), Ankara.

Katib Çelebi, (1980). Tuhfetü'l-Kibar fi Esfari'l-Bihar, C.I., İstanbul.

Kitab-1 Bahriye, https://dl.wdl.org/9210/service/9210.pdf Accessed 3 April 2019.

McIntosh, G. C., (2000). The Piri Reis Map of 1513, The University of Georgia Press, Athens GA and London.

Özen, M. Esiner, (1998). Piri Reis and his Charts, İstanbul.

Piri Reis Map, (2014). Turkish Naval Forces, Office Of Navigation, Hydrography and Oceanography Publication, İstanbul.

Sarıcaoğlu, Fikret, (2002). Kitab-1 Bahriyye, DİA, 71-73.

Soucek, Svat, (1992). "Islamic charting in the Mediterranean", The History of Cartography Vol. 2. book on: Edited by J. B. Harley and David Woodward, Cartography in the Traditional Islamic and South Asian Societies, 263-92.

Tekeli, Sevim, (1985). "The Map of America by Pîrî Reis", Erdem, 3, 673-683. 